\title{
Zooarchaeological Approaches to the Identification of Bone Fat Production in the Archaeological Record
}

\author{
Tanya M. Peres ${ }^{1^{*}}$ \\ ${ }^{1}$ Department of Anthropology, Florida State University, Tallahassee, FL, USA \\ *tanya.peres@fsu.edu
}

\begin{abstract}
Mammal fat is an important industrial product and ingredient in culinary dishes and medicines the world over, yet evidence for its use is not often identified in the archaeological record. I first give a brief overview of the importance of bone fats to subsistence and industrial economies. I follow this with criteria for identifying these activities archaeologically. This review concludes with why the identification of such activities is important to our understanding of ancient foodways.

Received March 19, 2018

OPENӘACCESS

Accepted May 22, 2018

DOI 10.14237/ebl.9.2.2018.1291
\end{abstract}

Keywords Zooarchaeology, Resource intensification, Food insecurity, Cuisine, Foodways

Copyright (c) 2018 by the author(s) licensee Society of Ethnobiology. This is an open-access article distributed under the terms of the Creative Commons Attribution-NonCommercial 4.0 International Public License (https://creativecommons.org/licenses/by-nc/4.0), which permits non-commercial use, distribution, and reproduction in any medium, provided the original author and source are credited.

Globally, fats procured from mammal bones were an important nutritional, medicinal, and industrial resource. Bone fat extraction is a way to maximize all parts of a prey animal and can be identified in the archaeological record. There are many reasons hunter-gatherer economies included bone grease as a dietary staple; nutritionally it is dense in energy and fatty acids and is an important source of trace vitamins and minerals. It aids in the digestion of protein, thiamine, and liver glycogen and prevents those who consume a diet high in lean meats from developing protein poisoning (Church and Lyman 2003; Speth 2010; Speth and Spielmann 1983; Vehik 1977). From ethnographic and historic documents we know that bone grease was used industrially for tanning hides, fuel, tallow, skin or hair lotion, mosquito repellant, in medicinal recipes, in paints, and for polishing bone and stone implements (Battle 1922; Grinnell 1972).

The earliest evidence for marrow extraction is from Plio-Pleistocene sites in Africa (Blumenschine and Madrigal 1993; Bunn 1981) with more recent work showing marrow and grease extraction to be an important part of numerous economies across the globe (Bar-Oz and Munro 2004; Karr et al. 2014; Outram 2004; Parmenter 2015; Peres 2018; Speth and Spielmann 1983). However, the identification of bone grease and fat processing is not part of routine zooarchaeological analyses or interpretations. For the most part, equifinality is to blame for the lack of research into identifying this ancient and nearuniversal activity, though this can be overcome with a multivariate approach (Bar-Oz and Munro 2004). In reviewing the published literature, a number of studies provide the methods necessary to demonstrate the presence of bone grease rendering in archaeofaunal assemblages.

\section{Making Fat Extraction Data a Routine Practice in Zooarchaeology}

Numerous zooarchaeological studies have shown that bone fat extraction is an identifiable and quantifiable cultural activity (Morin and Soulier 2017; Mulville and Outram 2005; Outram 2001), yet few projects regularly collect the necessary data to understand this at the site or regional level. Zooarchaeologists typically collect a standard set of data from every assemblage, including taxon, element, portion/ completeness, count, bone weight, and modifications. These data can then be analyzed for markers of marrow extraction and/or grease production (Table 1). The reader is referred to previous studies for indepth descriptions of specific methodologies and approaches (Bar-Oz and Munro 2004; Binford 1978; Karr 2015; Outram 2001; Prince 2007; Wolverton et al. 2008). Mammals have two types of bone: cortical 
Table 1 Categories of criteria in archaeological studies of bone marrow and fat processing.

\begin{tabular}{|c|c|c|c|}
\hline & Meat Only & Marrow Extraction & Grease Production \\
\hline Taxa & large mammals & large mammals & $\begin{array}{l}\text { large mammals, though } \\
\text { visual identifications may be } \\
\text { difficult }\end{array}$ \\
\hline Element representation & intact longbones & longbones, vertebrae & $\begin{array}{l}\text { vertebra, cancellous } \\
\text { epiphyses }\end{array}$ \\
\hline \multirow[t]{5}{*}{ Modifications } & $\begin{array}{l}\text { no fractures, fragmentation, } \\
\text { or splinters }\end{array}$ & $\begin{array}{l}\text { breaks on green/fresh bone } \\
\text { (Fracture Freshness Index) }\end{array}$ & $\begin{array}{l}\text { intensity of fragmentation: } \\
\text { heavily fragmented }\end{array}$ \\
\hline & & $\begin{array}{l}\text { extent of fragmentation: iden- } \\
\text { tifiable diaphyses with no or } \\
\text { one epiphysis }\end{array}$ & \\
\hline & & spiral-fractured longbones & \\
\hline & & $\begin{array}{l}\text { diaphyses or epiphyses with } \\
\text { bash marks }\end{array}$ & \\
\hline & & bone flakes/splinters & \\
\hline \multirow[t]{3}{*}{ Context } & found in numerous contexts & sheet midden, features & $\begin{array}{l}\text { recovered with associated } \\
\text { tools (anvils, hammerstones) } \\
\text { and features (hearths) }\end{array}$ \\
\hline & & & $\begin{array}{l}\text { recovered in association with } \\
\text { grease residue }\end{array}$ \\
\hline & & & $\begin{array}{l}\text { discrete deposit of } \\
\text { fragmented bone }\end{array}$ \\
\hline
\end{tabular}

and cancellous. Cortical bone is the dense and compact outer surface that protects the inner cavities of bones such as the diaphyses (shafts) of long bones. These inner cavities are where bone marrow, congealed fat deposits, is stored. Cancellous, or trabecular, bone is the inner layer of bone and is spongy in appearance. The epiphyses (ends) of, and some portions inside, long bones are made up of cancellous bone. Bone grease is found in the spongy epiphyses of long bones and in the cancellous centra of vertebrae, ribs, carpals, tarsals, patellae, innominates, and crania.

If large mammal bones in a given faunal assemblage were processed only for meat, we would expect to have a majority of intact long bones free of green bone fractures. These bones would be readily identifiable to taxon, element, side, etc. In an assemblage that was processed for bone marrow, we would expect to see a pattern of long bones fractured and splintered or spiral fractured as a result of being struck and broken open while still fresh, resulting in splintered shafts and relatively unharmed epiphyses.

In an assemblage where bones were also processed for the fat stored within the cancellous portions, we expect further damage and crushing to be apparent. The most efficient and effective way to maximize grease extraction is to crush cancellous bones into small pieces, boil them in water for several hours, then skim the fat off the top (Church and Lyman 2003). Indeed, discrete areas for this activity have been identified at several sites from the American Great Plains (Baker 2009; Karr et al. 2014).

\section{Importance of Bone Fat to Ancient Economies}

Archaeologists need to document evidence of bone fat extraction to better understand ancient economies. These data allow us to understand the differential processing of various taxa and how they were 
important to a community (i.e., some animals may have been important sources of subcutaneous fat, meat only, or bone and antler raw material). We can use bone fat data to assess changes in food preferences or harvesting methods over time. In many cases bone marrow and/or grease extraction is part of an overall intensification of subsistence resources. Intensification may be due to population increase, environmental changes, or some combination thereof. Ultimately, the goal of archaeological research is to provide more information about the cultural activities that took place at a given site. The zooarchaeological identification of the processing of animals for bone fats will enhance our understanding of how animals were incorporated into ancient cuisines, medicinal remedies, and industrial goods.

\section{Acknowledgements}

I offer thanks to the three anonymous reviewers and John Marston for their helpful comments and suggestions on an earlier version of this paper.

\section{Declarations}

Permissions: Not applicable.

Sources of Funding: None declared.

Conflicts of Interest: None declared

\section{References Cited}

Bar-Oz, G. and N.D. Munro. 2004. Beyond Cautionary Tales: A Multivariate Taphonomic Approach for Resolving Equifinality in Zooarchaeological Studies. Journal of Taphonomy 2:201-221.

Binford, L. 1978. Nunamiut Ethnoarchaeology. Academic Press, New York, NY.

Blumenschine, R.J., and T.C. Madrigal. 1993. Variability in Long Bone Marrow Yields of East African Ungulates and its Zooarchaeological Implications. Journal of Archaeological Science 20:555587. DOI:10.1006/jasc.1993.1034.

Bunn, H.T. 1981. Archaeological Evidence for MeatEating by Plio-Pleistocene Hominids from Koobi Fora and Olduvai Gorge. Nature 291:574-577. DOI:10.1038/291574a0.

Church, R.R., and L.R. Lyman. 2003. Small Fragments Make Small Differences in Efficiency When Rendering Grease from Fractured Artiodactyl Bones by Boiling. Journal of Archaeological Science 30:1077-1084. DOI:10.1016/S0305-4403(03)00010-4.
Karr, L.P., A.E.G. Short, L.A. Hannus, and A.K. Outram. 2014. A Bone Grease Processing Station at the Mitchell Prehistoric Indian Village: Archaeological Evidence for the Exploitation of Bone Fats. Environmental Archaeology 20:1-12. DOI:10.1179/1749631414Y.0000000035.

Morin, E. and M. Soulier. 2017. New Criteria for the Archaeological Identification of Bone Grease Processing. American Antiquity 82:96-122. DOI:10.1017/aaq.2016.16.

Mulville, J. and A. Outram. 2005. The Zooarchaeology of Fats, Oils, Milk, and Dairying. Oxbow, Oxford, UK.

Outram, A.K. 2001. A New Approach to Identifying Bone Marrow and Grease Exploitation: Why the "Indeterminate" Fragments Should Not be Ignored. Journal of Archaeological Science 28:401-410. DOI:10.1006/jasc.2000.0619.

Peres, T.M. 2018. Splitting the Bones: Marrow Extraction and Mississippian Period Foodways. In Baking, Bourbon, and Black Drink: Foodways Archaeology in the American Southeast, edited by T.M. Peres and A. Deter-Wolf, pp. 30-50. University of Alabama Press, Tuscaloosa, AL.

Prince, P. 2007. Determinants and Implications of Bone Grease Rendering: A Pacific Northwest Example. North American Archaeologist 28:1-28. DOI:10.2190/NA.28.1.a.

Speth, J.D. 2010. The Paleoanthropology and Archaeology of Big-Game Hunting: Protein, Fat, or Politics? Interdisciplinary Contributions to Archaeology. Springer, New York, NY. DOI:10.1007/978-1-4419-6733-6.

Speth, J.D., and K.A. Spielmann. 1983. Energy Source, Protein Metabolism, and Hunter-Gatherer Subsistence Strategies. Journal of Anthropological Archaeology 2:1-31. DOI:10.1016/0278-4165(83) 90006-5.

Vehik, S.C. 1977. Bone Fragments and Bone Grease Manufacturing: A Review of Their Archaeological Use and Potential. Plains Anthropologist 22:169-182. DOI:10.1080/2052546.1977.11908805.

Wolverton, S., L. Nagaoka, J. Densmore, and B. Fullerton. 2008. White-Tailed Deer Harvest Pressure and Within-Bone Nutrient Exploitation During the Mid-to-Late Holocene in Southeast Texas. Before Farming 2008:1-23. DOI:10.3828/ bfarm.2008.2.3. 